Gut, 1982, 23, 712-715

Case report

\title{
'Nodular necrobiosis': a new cutaneous manifestation of Crohn's disease?
}

\author{
CLAIR DU BOULAY and P J WHORWELL
}

From the Department of Pathology, Southampton University Hospital, Southampton, and the Department of Medicine, University Hospital of South Manchester, Manchester

SUMmARY A skin lesion previously unassociated with Crohn's disease is described. Although superficially resembling erythema nodosum it runs a different clinical course and has different histological appearances, the central feature being necrobiotic collagen. The term 'nodular necrobiosis' is suggested.

Extraintestinal manifestations of inflammatory bowel disease are many and well described. ${ }^{12}$ There have been accounts of histological changes of Crohn's disease occurring in the skin $^{34}$ distant from the perianal area where the characteristic changes of induration, oedematous skin tags, and fissures occur. ${ }^{56}$

Other skin manifestations which bear no histollogical resemblance to the primary lesion include pyoderma gangrenosum, erythema nodosum, cutaneous polyarteritis nodosa, and erythema multiforme. ${ }^{278}$ We describe a skin lesion found in association with Crohn's disease that visually resembles erythema nodosum, but which has a completely different natural history and histology.

\section{Case histories}

CASE 1

A woman, born on 27 January 1957, presented with diarrhoea, mucus, and blood in 1977. Barium enema revealed ulceration of the descending colon, but the rectum was only slightly inflamed on sigmoidoscopy. She was treated with systemic corticosteroids and sulphasalazine and made a good response. She had a further exacerbation in 1978, which responded well to systemic steroids, although her bowel habit never returned completely to normal. She had another relapse in 1980, initially treated with $40 \mathrm{mg}$ prednisone daily, and since then has been receiving maintenance steroids ( $10 \mathrm{mg}$ daily) with good relief of bowel symptoms. She is not taking any other

Received for publication 16 November 1981 medication and has no evidence of glucose intolerance.

\section{Current investigations}

Haemoglobin was $14.6 \mathrm{~g} / \mathrm{dl}$; ESR $11 \mathrm{~mm} / \mathrm{h}$. Autoimmune profile including sheep cell agglutination test (SCAT) was negative. Immunoglobulin and complement levels were normal. Colonoscopy showed a cobblestone appearance consistent with Crohn's disease of the large intestine with deep irregular ulcers. The rectum was spared and there was a skip lesion in the transverse colon. The terminal ileum was normal. Biopsies showed severe patchy inflammation with preservation of architecture and goblet cells. No granulomas were identified but the histological appearances supported the clinical and endoscopic findings.

\section{Skin manifestations}

She first developed hard, tender, purple lumps on her legs some weeks before her relapse in 1978. The lesions were reminiscent of erythema nodosum (Fig. 1) but have never faded. They have varied in intensity with occasional pruritus. Some have spontaneously ulcerated and healed again. They have been unaffected by the activity of the disease or any medication and withdrawing sulphasalazine produced no improvement. She has no other extraintestinal manifestations of inflammatory bowel disease except mild arthralgia of the knees.

CASE 2

A woman, born on 16 March 1920 , presented with diarrhoea and abdominal pain in 1955. Barium 
Fig. 1 Case 1. Nodules on lower leg resembling erythema nodosum.

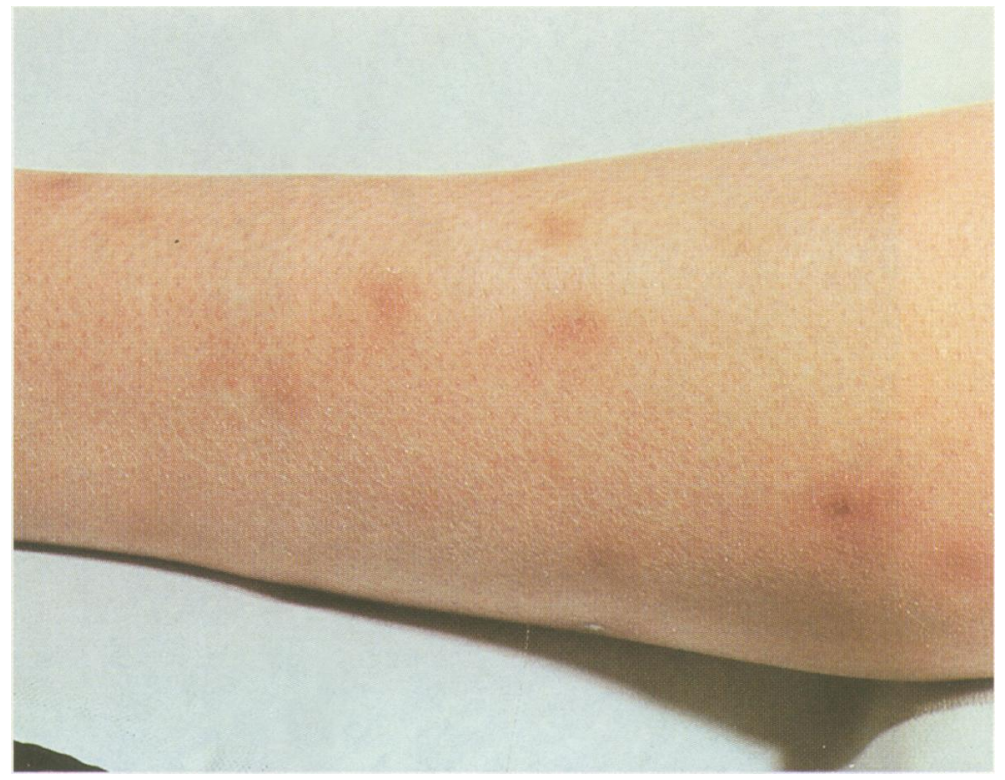

follow through examination showed Crohn's disease of the terminal ileum. She had resections of small bowel in 1956, 1958, 1963, 1973, and 1980. Histological examination showed typical changes of Crohn's disease, including non-caseating epithelioid granulomas with giant cells. She was treated with two short courses of prednisone in 1970 and 1979 (30 mg daily) without beneficial effect. She was started on azathioprine with some improvement in 1974 and has been on this drug since that time. At the present time, her Crohn's disease is still active, with radiological evidence of recurrence. She also has clinical and biochemical features of malabsorption. There is no evidence of glucose intolerance. Her brother also has Crohn's disease.

\section{Current investigations}

Haemoglobin was $14.6 \mathrm{~g} / \mathrm{dl}$; ESR $11 \mathrm{~mm} / \mathrm{h}$. Serum calcium was $2.11 \mathrm{mmol} / \mathrm{l}$ and serum magnesium 0.45 $\mathrm{mmol} / \mathrm{l}(0 \cdot 70-0 \cdot 95)$. Faecal fat excretion $82 \mathrm{mmol} / 24$ h (normal range $<18 \mathrm{mmol} / 24 \mathrm{~h}$ ). Autoimmune profile including SCAT was negative, and immunoglobulin and complement levels were normal.

\section{Skin manifestations}

She first developed a scaly itchy rash on her legs in 1972 , and over the years her legs have gradually become more indurated. In the last four years she has had several purple raised areas on both legs, reminiscent of erythema nodosum. The areas are itchy, slightly tender, and do not vary in size, intensity, or discoloration. Superficial ulceration occurred in one area after minor trauma but healed spontaneously. The skin lesions are unaffected by either the activity or her Crohn's disease or any of the medications that she has taken. She has no other extraintestinal manifestations of inflammatory bowel disease, except mild arthralgia of the knees.

\section{COMMENTS}

\section{Pathology}

Histology of the skin lesions in both cases was remarkably similar.

In each case, the overlying epidermis was normal. There were large, poorly-defined areas of necrobiosis of collagen in the lower dermis. The collagen bundles appeared degenerate and were mingled with amorphous, eosinophilic material. At the margins of the necrobiotic areas, scattered throughout the dermis and extending into subcutaneous fat, there was an inflammatory infiltrate composed of lymphoid cells, histiocytes, and epithelioid cells (Fig. 2). Foreign body giant cells were present and appeared to contain eosinophilic, degenerate collagen.

In case 1 the giant cells were present in wellformed non-caseating granulomata, whereas in case 2 they were scattered singly around the necrotic areas (Fig. 3). Although there was no evidence of 


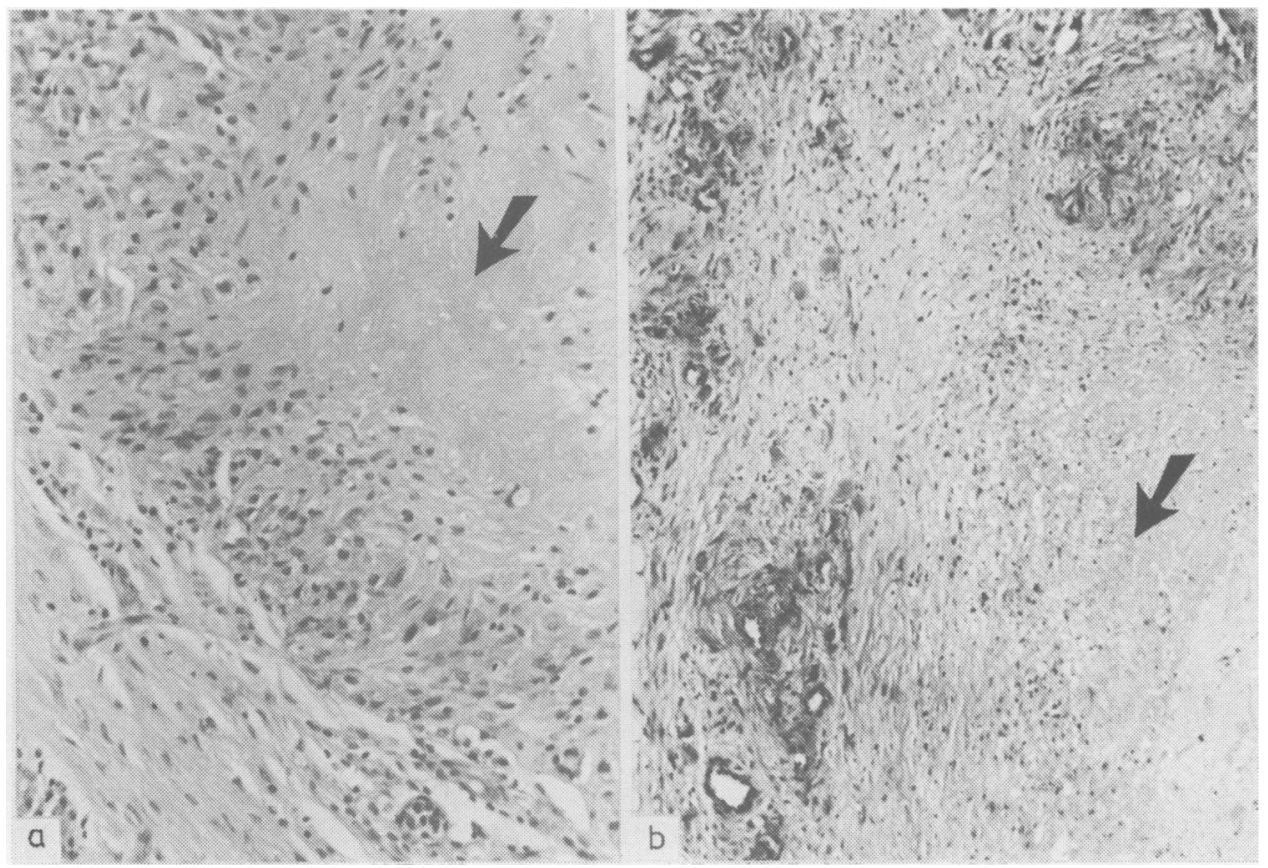

Fig. 2 (a) Case 1. (b) Case 2. Areas of necrobiotic collagen (arrows) with surrounding chronic inflammatory infiltrates, (a) $H$ and $E \times 50$, (b) $H$ and $E \times 20$.

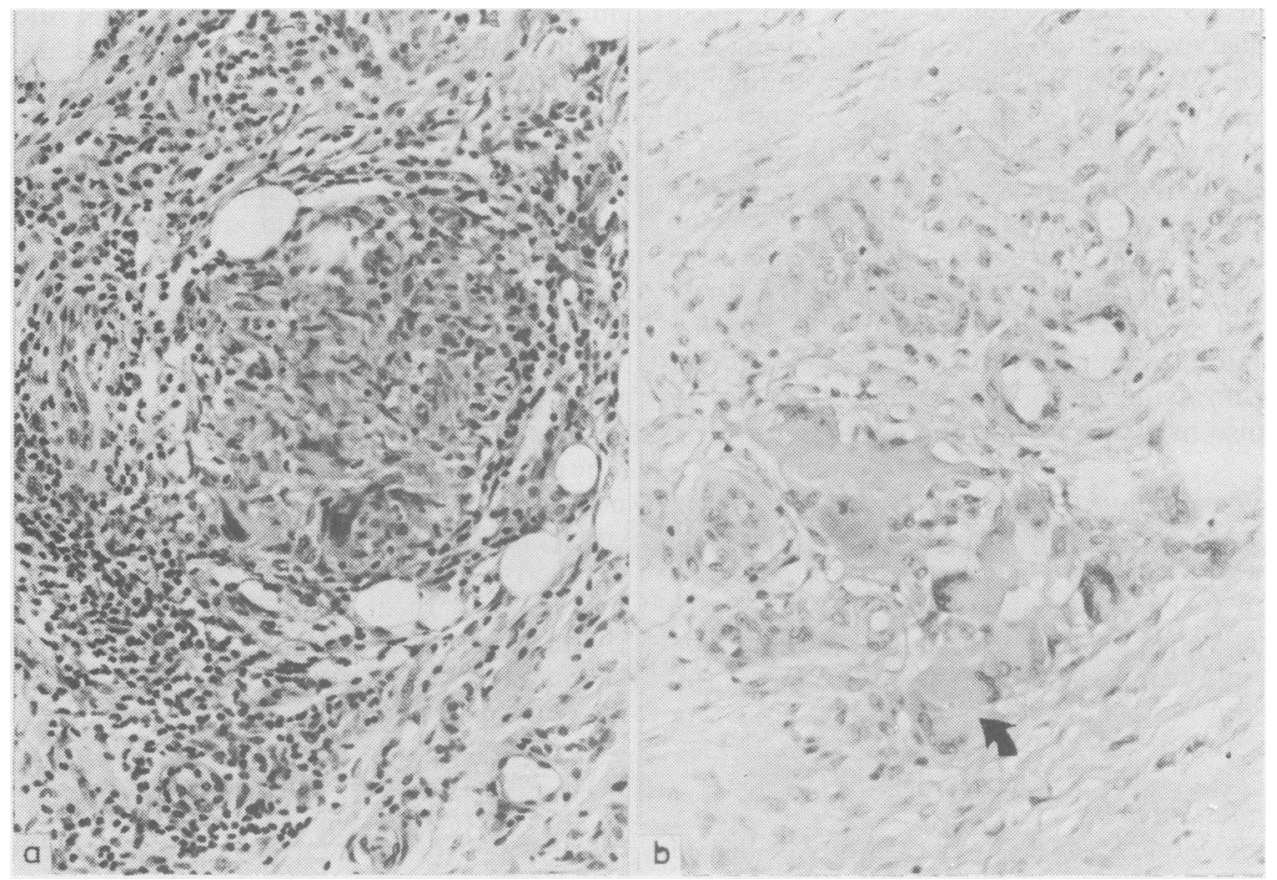

Fig. 3 (a) Case 1. Non-caseating granuloma. $H$ and $E \times 50$. (b) Case 2. Giant cells containing eosinophilic material (arrow). $H$ and $E \times 50$. 
vasculitis, the arterioles of the lower dermis showed marked intimal thickening.

Gram stains and Ziehl Nielsen stains for acid-fast bacilli were negative in each case, as was immunohistochemical (immunoperoxidase) staining for $\mathrm{C}_{3}$, $\mathrm{C}_{4}, \mathrm{IgG}, \mathrm{M}, \mathrm{A}$, and $\mathrm{D}$.

\section{Discussion}

The skin lesions described in these two cases of Crohn's disease have distinct clinicopathological appearances which have not been previously described.

The lesions were associated with a mild arthralgia of the knees, but otherwise ran a course independent of the activity of the Crohn's disease. In addition corticosteroid therapy had no effect.

Clinically these lesions bear some resemblance to erythema induratum and are closely similar to erythema nodosum. The nodules of erythema induratum are smaller and occur on the sides or the backs of the calves. Histologically, there is a vasculitis in the subcutaneous tissues and no dermal necrosis in contradistinction to what was observed in our patients. Erythema nodosum has a wellrecognised association with Crohn's disease ${ }^{1}{ }^{2}$ but the chronicity, lack of response to steroids, and different histological picture make this diagnosis untenable. Biopsy is not usually undertaken in erythema nodosum, for which these lesions could clinically easily be mistaken, and thus the histological features of necrobiotic collagen with surrounding epithelioid and giant cells may be missed. This histological picture is much more characteristic of the type of lesions seen in necrobiosis lipoidica, rheumatoid nodules, or granuloma annulare. ${ }^{9}$ Necrobiosis lipoidica may be associated with diabetes mellitus but neither of these patients had clinical or biochemical evidence of this disorder. Neither patient had any serological evidence of rheumatoid arthritis.

The pathogenesis of necrobiotic lesions such as these is unknown. It seems unlikely that an immuno- logical mechanism could account for the appearances as there was no vasculitis or evidence of immune complex deposition as shown by immunohistochemical staining. The presence of necrobiotic collagen seems to be the central feature of these lesions and we suggest that the term 'nodular necrobiosis' would be appropriate for this extraintestinal manifestation of Crohn's disease.

We would like to thank Professor $\mathrm{R}$ Wright for allowing us to report the cases under his care, Dr $\mathbf{J}$ White (consultant dermatologist) for arranging the skin biopsies and $\mathrm{Dr}$ B Leppard (consultant dermatologist) for helpful advice.

\section{References}

1 Smith JN, Winship DH. Complications and extraintestinal problems in inflammatory bowel disease. Med Clin North Am 1980; 64: 1161-71.

2 Greenstein AJ, Janowitz HD, Sachar DB. The extraintestinal complications of Crohn's disease and ulcerative colitis: a study of 700 patients. Medicine (Balt) 1976; 55: 401-12.

3 Mountain JC. Cutaneous ulceration in Crohn's disease. Gut 1970; 11: 18-26.

4 Witkowski JA, Parish L, Lewis JE. Crohn's disease non-caseating granulomas on the legs. Acta Derm Venereol (Stockh) 1977; 57: 181-3.

5 Gray BK, Lockhart-Mummery HE, Morson BC. Crohn's disease of the anal region. Gut 1965; 6: 515-24.

6 Fielding JF. Perianal lesions in Crohn's disease. $J R$ Coll Surg Edinb 1972; 17: 32-7.

7 Kahn EI, Davm F, Aiges HW, Silverberg M. Cutaneous polyarteritis nodosa associated with Crohn's disease. Diss Colon Rectum 1980; 23: 258-62.

8 Brenner SM, Delaney HM. Erythema multiforme and Crohn's disease of the large intestine. Gastroenterology 1972; $62: 479$.

9 Lever WH. Histopathology of the skin. Philadelphia: Lippincott, 1975: 214-22. 